\title{
Toward a Materialist-Formalist History of Twentieth-Century Irish Literature
}

\section{Joe Cleary}

1

Most accounts of contemporary Irish culture tend to be largely affirmative, even Whiggish, in cast. The contemporary cultural moment is recurrently described as one characterized by renaissance, experiment, and iconoclasm, a moment vitalized by the emergence of radical new voices, styles, media, forms, and energies. This upbeat view is clearly underpinned by a broader sociohistorical narrative, also of a decidedly Whiggish temper, in which contemporary Irish society is construed as one engaged over recent decades in an often laborious, but on the whole overwhelmingly successful, overcoming of a more repressive, provincial, censorious past. As Irish society leaves behind that past to become more liberal, secular, postnationalistic, multicultural, more confidently European in its outlook, contemporary Irish culture - the account runs - gives imaginative expression to this dynamic process of social change.

The very concept of what I have been referring to as "the contemporary cultural moment" presupposes some kind of watershed that allows us to distinguish between "the way things are now" and "the way they were 
before." In most of the surveys that document the achievements of the present, however, it is precisely the absence of any serious attempt to establish what (if indeed anything) is decisively new about the present cultural moment that is most conspicuous. Every decade will produce its own cultural novelties (one recalls Walter Benjamin's remark that "fashion is the eternal recurrence of the new"), but in this restricted sense no decade can be considered qualitatively different from any other, and by such measure the 1980s and 1990s are no different, say, from the 1940s or 1950s. Yet when commentators discuss contemporary Irish culture, they generally appear to make some stronger claim for the present than the mere fact of novelty in this basic sense. The usual claim is that the emergence of new women writers, of the new urban writing, and the successes of the Irish film or music industries collectively amount to something more significant than the perennial turnover of personnel and seasonal fashion.

The point I am arguing here is that any strong conception of "the contemporary moment" is always defined in terms of a break with or modification of the cultural system that preceded it. Such claims presuppose some kind of literary periodization, some implicit model of cultural history, but surveys of contemporary Irish culture have tended to evade explicit theoretical engagement with such tasks. One might even argue that the (now extended) Field Day Anthology has furnished Irish studies with something like a viable canon of Irish literature (one that is, to be sure, like all canons, gapped, tendentious, and contested), but that we still lack serious materialist attempts to historicize Irish literary and cultural production. Marxist critics have always had a special commitment to the historical analysis of culture, notably the ambitious models of cultural history developed by such leading figures as Georg Lukács and Fredric Jameson. It is no exaggeration to say that the historical schemata that underpin their works have become something like the assumed "common sense" of much leftist cultural criticism and thus will be broadly familiar.

The difficulty with the historical schemas developed by Lukács and Jameson is that they cannot easily be transposed onto the Irish situation. Whatever their differences otherwise, these Marxist cultural histories are elaborated with a metropolitan European or Euro-American capitalist history in mind. Lukács's work takes its bearings primarily from French and German (and to a lesser extent English and Russian) literary history; Jameson's addresses itself to a continental Western European (England, France, Germany) and U.S. context (though his later work tries to extend the frame). From well before the modern period, however, Irish history had evolved in 
ways that did not conform in some decisive respects to developments in the metropolitan cultures that inform Lukács's or Jameson's works. To begin with, Ireland had escaped the conquest of Roman imperialism, in contrast to most of Western Europe, and was, in Brendan Bradshaw's words, "no more than superficially touched by the cultural and institutional cargo" which that empire brought with it. ${ }^{1}$ It was out of that institutional cargo that medieval European feudalism emerged when the Roman Empire collapsed, but, with the exception of the areas controlled by the Anglo-Norman invaders in the south and east, the feudal system never substantially penetrated Ireland. Later, in the modern period, when other Western European countries such as Portugal, Spain, Holland, England, France, Belgium, and eventually Germany became, each for a time at least, successive centers of capitalist and imperial expansion, Ireland was the only country in that geographical area to be subjected to a sustained, thoroughgoing, and culturally traumatic experience of colonization. For its nearest neighbors, modernity was synonymous with the assumption of key structural positions in the emerging capitalist world system, with the accumulation of wealth, monopolization of the means of violence, national aggrandizement, and the sense of cultural distinction that attended this.

For Ireland, in contrast, modernity meant dispossession, subordination, and the loss of sovereignty, the collapse of its indigenous social order, the gradual disintegration of the Gaelic cultural system, and successive waves of politically or economically enforced emigration. Capitalist modernity in Ireland, in other words, advanced within a colonial regime under which the country remained the most chronically unstable and rebellious location within the British archipelago from the early modern period until the late twentieth century. Whereas other Western European economies were dramatically transformed in the nineteenth and early twentieth centuries by the first and second industrial revolutions, most of Ireland remained nonindustrialized, and its economy continued to be, until very recently, unusually dependent for a Western European region on export-oriented agricultural production. The colonial legacies of economic subordination and dependency, technological underdevelopment, massive emigration to the industrial centers of Britain and the United States, and sectarian violence inscribed in a postcolonial partitionist state order have conditioned much of the shape and texture of twentieth-century Irish history.

1. Brendan Bradshaw, "Irish Nationalism: An Historical Perspective," Bullán: An Irish Studies Journal 5, no. 1 (Summer/Fall 2000): 5. 
Because Marxist models of history have assumed as normative the transition from feudalism via absolutism to mercantile and, later, industrial capitalism, or a series of structural modulations within capitalism of the kind described by Ernest Mandel, Irish history has always proved quite recalcitrant to conventional Marxist emplotment. To take a particularly vivid example, when mid-nineteenth-century English capitalist development issued in the Industrial Revolution that made Great Britain "the workshop of the world," Ireland was devastated by the social catastrophe of the Great Famine. While one society, in other words, was being transformed by developments that would bring it to the apex of its industrial and imperial glory, the other was being transmogrified by what we might call an early Victorian holocaust. ${ }^{2}$ Nevertheless, while this massive discrepancy in national experience speaks for itself, the real challenge posed by these concurrent developments is to conceive of them not as two altogether alien and disjunctive histories but rather as two divergent vectors of the same modernization process. The particular theoretical challenge of the Irish situation, in other words, is to be able to deal with the ways in which the country has developed by capitalist modernizing processes quite different from those in the major metropolitan European and American countries, while simultaneously allowing for the fact that its distinct development has always been shaped and conditioned by capitalist developments in these core areas. The challenge, in other words, is to steer a course between a Scylla that would simply stress Ireland's sameness to the metropolitan states, thereby effacing difference to press Ireland into a standard metropolitan template, and a Charybdis that would stress only its fundamental alterity (its exceptional or anomalous or aberrant elements) to the metropolitan centers.

To say that Ireland's condition has been one of "colonial peripherality" is not at all to suggest that it has developed somewhere entirely beyond the pale of metropolitan modernity. On the contrary, to be peripheral is precisely to be compelled to develop within constraints, sets of forces, and agendaseconomic, political, cultural, intellectual - that have largely been prescribed or conditioned by developments in the metropolis. To think beyond current orthodoxy in Irish social and cultural history-which usually construes Ireland as only badly and belatedly catching up with a model of modernization immaculately completed much earlier in Europe-we need to work toward

2. The term alludes to Mike Davis's remarkable Late Victorian Holocausts: El Niño Famines and the Making of the Third World (London: Verso, 2001), which suggests that the Irish Famine might be viewed as an early precursor to a wider global series of late Victorian modernizing catastrophes. 
a less linear and more global and conjunctural mode of analysis that starts from the assumptions that Irish modernity comprises a particular configuration of wider global processes, and that its modernity is therefore directly coeval with other modernities. But coeval here suggests a contemporaneity that recognizes the possibility of difference.

In this essay, I want to take a long view of twentieth-century Irish literary and cultural history by situating that history in terms of a wider metropolitan European and Euro-American transition from modernism to postmodernism of the kind theorized by Marxist critics such as Jameson and Perry Anderson. Though Jameson's work on modernism and postmodernism is the much better known of the two, Anderson's will also be considered here because it has usefully "rewritten" Jameson in ways that attempt to reinsert social and political levels that Jameson's work, focused overwhelmingly as it is on cultural developments as a response to changes in the economic base, generally overrides. To many Irish critics, a venture of this kind will seem quixotic and misconceived. For some, the value of such large-scale historical frameworks will seem unconvincing, tidying the interesting messiness of Irish cultural history into an overly orderly succession of cultural dominants. For others, the canonical bent of literary histories of this sort will, not unjustifiably, raise questions. For still others, what is really called for is an entirely new kind of cultural history less indebted to Eurocentric Marxian metanarratives.

While the project envisaged here undoubtedly remains vulnerable to these criticisms, it is questionable whether it could ever be possible to elaborate an entirely new model of cultural history that would avoid all of these pitfalls. Of these various critiques, the most urgent one claims that the Eurocentrism of Marxist cultural criticism cannot but conscript Irish cultural history into an apparently metropolitan register that is really only a provincially Western European or Euro-American one, and in so doing simultaneously impedes the development of a genuinely global frame of reference capable of embracing locations beyond Europe. It is undoubtedly the case that while we have had many studies of, let us say, the Irish Revival that always implicitly compare it (usually negatively) with other contemporary Western European modernisms, that Revival might look very different indeed were we to think of it more in terms of other broadly contemporary cultural and intellectual "renaissances" elsewhere, such as, for example, those in Bengal, Harlem, or Mexico. For the moment, however, the research and resources that would make this kind of usefully estranging project possible are still underdeveloped. In any event, the issue is not whether we situ- 
ate Irish cultural history in a European context or a more broadly colonial and global one; the real question is how best to do both.

My working assumption is that while the works of Western Marxists such as Jameson and Anderson are indeed problematically Eurocentric, and ought not, by any means, to be slavishly adapted to Irish circumstances, Ireland nonetheless does not exist somewhere entirely "outside" of the histories of capital and culture theorized by these Marxist cultural historians. The history of Euro-American capital and culture, in other words, is not the universal history Marxists have taken it to be, but that history has nonetheless impressed itself on developments in most parts of the world, and more heavily on Ireland, perhaps, because of its location, than on many other colonized regions.

\section{2}

In Mandel's Late Capitalism, modern capitalism is deemed to have passed through three successive long economic cycles and systemic mutations, each characterized by its own distinct technologies, labor regimes, and sectoral dominants. ${ }^{3}$ Jameson's work rests on the idea that these three phase can be correlated to three major aesthetic dominants or macrostructures he calls realism, modernism, and postmodernism. The idea of an aesthetic "dominant" here refers to a cultural ascendancy that will never exhaust the entire phase in question but that designates, rather, the most novel and salient aesthetic forms of any period. The dominant aesthetic mode of a particular period, therefore, will always coexist with residual, contrapuntal, and emergent modes, as well, though the cultural dominant will, as Michael Walsh puts it, occupy "the hegemonic high ground within a given society at a historical moment." ${ }^{4}$ Radical breaks between one period and the next are not conceived as involving complete changes of content but rather as the restructuring of a certain number of elements already given: features that in an earlier period or system were subordinate now become dominant, and features that had been dominant again become secondary. ${ }^{5}$

The function of any decisive cultural transformation, Jameson con-

3. Ernest Mandel, Late Capitalism (London: Verso, 1975).

4. Michael Walsh, "Jameson and 'Global Aesthetics,'" in Post-Theory: Reconstructing Film Studies, ed. David Bordwell and Noël Carroll (Madison: University of Wisconsin Press, 1996), 482.

5. Fredric Jameson, "Postmodernism and Consumer Society," in Modernism/Postmodernism, ed. Peter Brooker (London and New York: Longman, 1992), 177. 
tends, "will be to invent the life habits of the new social world," to "deprogram" subjects trained in an older formation, and to provide imaginary resolutions to the contradictions and antinomies that constitute specific social contexts. Viewed thus, nineteenth-century "realism" was not simply an artistic copy or passive reflection of nineteenth-century society; its praxis, rather, was to de-program the older providential and sacred narratives of the precapitalist period and to provide new cultural paradigms of the subject's relations "to what now comes to be thought of as reality." ${ }^{6}$ To understand realism, therefore, we must grasp it as a component of the vaster historical project of the bourgeois cultural revolution, in which the whole economico-psychic structure of feudalism was dismantled and a new bourgeois economico-psychic subjectivity installed in its place. For Jameson, the essential task of the realist novel is twofold: on the one hand, to critique and corrode the sacred narratives of the older medieval world; on the other, to produce the new secular and disenchanted object world of the commodity system, the world of which it will then claim to be the "realistic" reflection.7

Modernism, for Jameson, is a cultural mode that emerges at a later moment, when capitalism dramatically extends its global reach (via imperialism), but when, nonetheless, "the technologically (or socially) modern was still little more than an enclave; in which the country still coexists with the city and still largely outweighs it." ${ }^{8}$ As Harry Harootunian puts it, glossing Jameson, it was the spectacle of lived unevenness in both the political, economic, and sociocultural domains that allowed modernism to develop, and it was the lived experience of this "simultaneous non-simultaneity" (Ernst Bloch) that modernism took as its predicate and problematic. ${ }^{9}$ Modernism, in sum, is a term that designates the matrix of possible aesthetic responses to a capitalist moment defined by this clash between old and new; it corresponds to the lived experience of the uneven temporalities of "simultaneous non-simultaneity." In his earlier writings, Jameson stresses that both modernism and mass culture must be conceived as dialectical counterparts. Whereas mass culture succumbs to the logic of the commodity (though not

6. Fredric Jameson, Signatures of the Visible (London and New York: Routledge, 1990), 164-66.

7. Fredric Jameson, The Political Unconscious (Ithaca, N.Y.: Cornell University Press, 1981), 152.

8. Cited in Santiago Colas, "The Third World in Jameson's Postmodernism, or, The Cultural Logic of Late Capitalism," Social Text 10 (1992): 261.

9. Harry Harootunian, Overcome by Modernity: History, Culture, and Community in Interwar Japan (Princeton, N.J.: Princeton University Press, 2000), xxii-xxiii. 
without retaining some muted capacity to express dissatisfied desires and utopian longing), the formally difficult experiments of modernism represent a desperate attempt to outflank the commodification process-though the price for this was that modernism lost touch with (and indeed mostly wanted to escape) the wider publics to which the great realists still had access..$^{10}$

For Jameson, the postmodern is "what you have when the capitalist modernization process is complete." 11 This moment is reached when capitalism has finally attained global reach, either abolishing all remaining precapitalist modes of production or subsuming them within its compass, and when it has also penetrated the unconscious and hence become normalized to the extent that we find it increasingly difficult to imagine either pre- or postcapitalist forms of existence. Jameson accepts that there is considerable formal, stylistic, and even thematic continuity between modernist and postmodernist cultural practice. But he insists that, despite such similarities, what matters is that cultural production is positioned and functions differently in the modernist and postmodernist periods, since, with the extension of commodity logic, the older distinctions between high and mass culture have now largely collapsed. In the postmodern period, the disintegration of unified subject positions, already symptomatically beginning to come apart in modernism, is now completed. This condition is generated not only by the dissolution of the unified bourgeois subject of early capitalism, however, but also by the disarticulation of any unified class subject as well, and the consequent elaboration of dissent in more fragmented, localized, and identitarian forms. Jameson does allow for some remaining pockets of resistance within the postmodern moment-identified with the underclass ghettos of the advanced capitalist world and with peripheral "Third World" formations-but these are not seriously or systematically integrated into his larger theory.

The relationship between the economic and cultural spheres is not conceived by Jameson as one of base-superstructure reflection; culture serves, rather, as a means of transcoding the dominant mode of production, so that the mediations between the two spheres become a central issue in his work. Nevertheless, even if Jameson allows for what Walsh calls "the complex semiautonomy of the cultural," ${ }^{12}$ because it is premised on track-

10. Fredric Jameson, "Reification and Utopia in Mass Culture," in Signatures of the Visible, 9-34.

11. Fredric Jameson, Postmodernism, or, The Cultural Logic of Late Capitalism (Durham, N.C.: Duke University Press, 1990), ix.

12. Walsh, "Jameson and 'Global Aesthetics," 484. 
ing the relationship between cultural production and very large-scale economic changes, the absent intermediate level in his work tends to be the political. In this respect, at least, Anderson's attempts to theorize modernism and postmodernism in terms of a complex conjuncture or intersection of diverse sociopolitical and economic forces represent a useful supplement to Jameson's model. One of Anderson's key concepts is that of the "conjuncture": a term that denotes the exact balance or configuration of forces, and the overdetermination of the contradictions that obtain within that balance, that can be said to constitute a particular historical moment.

For Anderson, it is significant that the most extensive European modernist movements emerged in the early twentieth century not in the most industrially advanced or most "modern" country of the time-England-but rather where complex conjunctures allowed for "the intersection of different historical temporalities." ${ }^{13}$ Modernism, he argues, emerged in continental Europe within a cultural force field comprised and triangulated by three coordinates. The first was the codification of a highly formalized academicism in the visual and other arts that drilled students in the major styles and masterpieces of the classical or neoclassical past. These academies were the cultural gatekeepers of states still massively dominated by aristocratic or landowning classes, which, though economically in relative decline, were still setting the political and cultural tone in the European countries before and even after World War I. The second coordinate was the incipient, hence essentially novel, emergence within these still largely preindustrial societies of the key technologies or inventions of the second industrial revolution: the chemical and synthetic industries, electric power, turbines, internal combustion engines, the telephone, radio, cinema, the automobile, the aircraft. Mass consumption industries, Anderson contends, were not yet implanted anywhere in Europe, however. A third decisive coordinate was the imaginative proximity of social revolution. In no European country at the start of the twentieth century was bourgeois democracy completed in the sense that adult suffrage was extended to all (women and many workers did not have the vote), and the insurgent labor movement still remained largely outside of the political system and had yet to be co-opted as a political force. The extent of hope or apprehension about revolution varied widely across Europe, but it was everywhere "in the air" during the belle epoque and especially after the Russian Revolution. Across Europe, then, the Old Order still

13. Perry Anderson, "Modernity and Revolution," in Marxism and the Interpretation of Culture, ed. Cary Nelson and Lawrence Grossberg (Houndmills: Macmillan, 1988), 324. 
clung on tenaciously in both the political and cultural spheres, but it was everywhere shadowed not only by the sweeping changes triggered by the still infant second industrial revolution but also by the specter of political revolution, and hence the moment was pervaded by a sense that the future was radically open-ended.

What was the specific contribution of each coordinate to the wider force field defining modernism? For Anderson, the persistence of the ancien régimes and the concomitant academicism of the state cultural institutions provided a key range of cultural values against which the modernist movements could define themselves. Without this common adversary, the wide range of new modernist artistic practices had little unity: it is their common hostility to the consecrated neoclassical, romantic, and realist canons, and to the cultural mortmain of the ancien régime academies and conservatories, that constitutes their identity as such. But if they rejected official academicism, many different modernist movements also rejected the commodity market as the alternative organizing principle of culture and society. If nothing else, the Old Order offered a conception of art as a higher vocation (predicated on conceptions of value at odds with capital logic) that was still available to the modernist artist. Finally, the combined stimuli produced by the wave of technological advances that defined the second industrial revolution and by the prospect of revolution lent the period an electric atmosphere-oscillating between apocalyptic anxiety and utopian hopein which it was possible to imagine a wholly transformed social order utterly unlike that which currently existed.

\section{3}

If, as Anderson suggests, modernist cultural currents were strongest not where industrialization and the new corporate capitalism were already most advanced but in situations of combined and uneven development, where relatively small industrial enclaves were hatched within an older aristocratic or predominantly agrarian and preindustrial order, then Ireland accords with this profile well enough. Late nineteenth-century Ireland possessed an unusually modernized state (itself a product of colonial rule), strong basic literacy levels in European terms, and Belfast was then the world's fifth largest industrial city. Nevertheless, on the island as a whole, the economy and workforce were still overwhelmingly rural, artisanal, and preindustrial. For many, a direct link can be traced between this retarded industrial and technological development and the supposed conservatism of 
Irish cultural production in the Revival period. In "The Archaic Avant-Garde," for instance, Terry Eagleton argues that Ireland in this period was every bit as much a capitalist formation as its British counterpart, but that the Irish variety "was a woefully inert form of rural capitalism, an old-fashioned form of modernity." Moreover, he contends, the prime mover of modernization in Ireland was "the rural middle class" ("one of the most conservative formations in Western Europe"), and that class "lacked the challenge of an industrial working class to spur it into life." 14 "There could be," he concludes, "no exhilarating encounter between art and technology in such an industrially backward country." 15

But Eagleton here seems to assume too automatic and unmediated a connection between economic base and culture. It is as though a largely rural society and rural middle class must inevitably produce a reactionary ruralist culture. Yet, as Anderson points out, it was precisely in the least industrially advanced European societies - namely, Italy and Russia-that the most militantly antitraditionalist modernist movements emerged, as exemplified by the Italian Futurists and the Russian Constructivists. But if these overwhelmingly rural countries produced militant avant-gardes that hymned technology and industrial transformation, this begs the question why something of this kind did not also occur in Ireland, where the industrial northeast might have functioned as crucible and stimulus in a manner not unlike, say, the industrialized north in agrarian Italy.

The answer here surely has to do not just with a rural middle class per se but with the vagaries of Ireland's colonial history, which had simultaneously transferred most of the Irish Catholic laboring classes abroad (by the 1860s, New York already had a larger Irish population than Dublin) and rendered the industrial northeast the most determinedly counterrevolutionary region in the entire island. Because of its fierce antipathy to Irish nationalism, and indeed to its supposed liberal allies in England, the northern Protestant industrial bourgeoisie and working classes had embraced the most conservative and chauvinistically imperialist versions of British identity and ideology ${ }^{16}$ The industrialized northeastern economy centered on Belfast, moreover, was tied integrally to the British economy, and while Britain had been the heartland of the first industrial revolution, its global preeminence

14. Terry Eagleton, Heathcliff and the Great Hunger: Studies in Irish Culture (London and New York: Verso, 1995), 277.

15. Eagleton, Heathcliff and the Great Hunger, 299.

16. See Gillian McIntosh, The Force of Culture: Unionist Identities in Twentieth-Century Ireland (Cork: Cork University Press, 1999). 
was actually threatened by the second, which allowed rivals such as Germany and the United States to emerge as new superpowers on the international scene. Hence, while in what had earlier been industrially backward places, such as Germany, Russia, or Italy, the second industrial revolution might generate a heady welter of excitement as they began to "catch up" with Britain and with each other, in Britain itself, the same developments augured a sense of imperial crisis and national decline.

Thus in an early twentieth-century context, when Britain was still the world's leading industrial superpower, the Belfast shipyards could produce the mighty ocean liners that were one of the major icons of twentieth-century technological daring and ambition. But the sinking of the Titanic, the mass slaughter of the Ulster regiments on the Somme in 1916, and the shrinkage of the Union due to Irish nationalist separatism collectively helped to ensure that in Unionist-dominated northern Ireland, as in Britain more generally, early twentieth-century modernity was culturally conceived of in terms of catastrophe, collapse, and decline-in terms of the sense of an endingrather than in rhapsodic or euphoric terms. In other words, in the industrialized northeast of Ireland, the advent of the twentieth century gave rise to a cultural posture of defensive siege largely inhospitable to the development of modernist art forms.

Thus, in Ireland the most industrialized enclave and the most substantial industrial working class were peculiarly aligned with the forces of British imperial tradition and counterrevolution, and hence did not produce a cultural modernist efflorescence of the kind that issued from other European industrial enclaves also encased within largely agrarian societies. It is also true that the technological advances of the second industrial revolution only lightly affected the island of Ireland as a whole. In the Irish situation, the discombobulating force that Anderson ascribes to this technological revolution had already been effected instead by a very different route: that is, by the devastation of the Great Famine. The effect of the second industrial revolution in Europe, as Anderson and others have suggested, was to corrode the old social order, dissolving its precapitalist elements, imploding traditional forms of everyday life and installing in their place new work practices, new modes of transport and communication, new kinds of social space, new gender relations, and so on. Decades before the second industrial revolution and the Great War did their work in continental Europe, the Famine in Ireland had arguably represented a merciless and accelerated convulsion of this magnitude, decimating the subaltern classes, accelerating the exodus from the land to the core industrial centers of England and America, com- 
pelling a shift to very different new property regimes at home, and, not least, dealing a final death blow to Gaelic culture. In 1849, William Wilde, father of Oscar, wrote that the Famine represented a "great convulsion which society here of all grades has experienced, the failure of the potato crop, pestilence, famine, and a most unparalleled extent of emigration, together with bankrupt landlords, pauperizing poor-laws, grinding officials, and decimating workhouses, have broken up the very foundations of social discourse. . . In some places, all the domestic usages of life have been outraged; the tenderest bonds of kindred have been severed, some of the noblest and holiest feelings of human nature have been blotted from the heart, and many of the finest, yet firmest links which united the various classes in the community have been burst asunder." 17 In Wilde's account, we find that same simultaneously dazed and amazed rhetoric, the same shocked sense of just how quickly the most sacrosanct bonds of a whole society can be shredded by an overwhelming force that is also registered in the famous "all that is solid melts into air" passage penned a year earlier by Marx and Engels in The Communist Manifesto. An estimated four million people left post-Famine Ireland between 1855 and 1914; this "headlong exodus" has been described by one leading present-day historian as "the instinctive reaction of a panicstricken people to the spectacle of their traditional way of life breaking into pieces before their very eyes." ${ }^{18}$

But for good reason the actual cultural dynamics of that event played out differently in Ireland than in other peripheral European societies. For the Italian Futurists and Russian Constructivists, the new technology of the second industrial revolution incited a sense of radical right- or left-wing fervor because it promised to dynamite a pathway to the future for societies that felt themselves smothered under the sheer excess of ossified ancien régime tradition. Technology, it was thought, would liberate these second-rate European powers from the mortmain of the once-glorious pasts that by the early twentieth-century seemed merely to be excess baggage that retarded their progress into the future.

In late nineteenth-century post-Famine Ireland, in stark contrast, the decisive preoccupation was not with how to discard the excess baggage of a once-splendid past but with the need to salvage something from the veritable wholesale decimation of tradition. Where for the Futurists mod-

17. William Robert Wilde, Irish Popular Superstitions (Dublin: J. McGlashan, 1852), 911. Cited in George Denis Zimmerman, The Irish Storyteller (Dublin: Four Courts Press, 2001), 208.

18. F. S. L. Lyons, Ireland Since the Famine (London: Fontana, 1985), 44. 
ern Italy had to blast its way out from under the opulent rubble of imperial Rome and the Renaissance to enter modernity, in Ireland the whole drive was not to shake off a once-glorious-now-moribund past but to recover or to invent an indigenous culture almost totally obliterated by centuries of colonialism, anglicization, and famine. To put it very simply, the Futurists might have felt that Italy was smothering under the excessive encumbrance of their once-glorious heritage, but, for the Irish, the real dilemma was that so much of the native heritage had already disappeared. At the distance of but a single generation from the lived trauma of the Great Hunger, a collective drive was under way to salvage something from the last great decimation of Gaelic culture in order to rebuild Ireland anew in terms that would not simply be British. The massive building program undertaken by the Catholic Church in the post-Famine decades, the campaign for a Catholic university, the establishment of the Gaelic Athletic Association (1884), the National Literary Society (1892), the Gaelic League (1893), the cooperative movement (1894), and the Irish Literary Theatre (1899) all belong, in discrepant and often fiercely antagonistic ways, to this wider institution-building drive that would issue in the creation of a new Irish state and social order. The Revival, therefore, is best seen not as a singular phenomenon but as a matrix of cultural responses to this wider post-Famine institution-building drive to create hegemonic national institutions and a national public, and it was in turn both out of - and also in reaction to - the cultural ferment created by the intersection of these broad popular movements that the modernist strands of the Revival would emerge. ${ }^{19}$

Given the context, the whole drive of the Revival was not so much to assault the existing network of venerable national cultural institutions in the manner of the European avant-gardes as to create the stately institutions the country was felt to lack, and in so doing to transform Dublin from a British satellite into an Irish cultural capital. Whereas in the established European states the modernist avant-gardes rebelled against the stifling atmosphere of their own prestigious national academies, in Ireland the cultural revolution took on, rather, the character of a dispute between literary core and periphery. The Irish Revivalists challenged London's cultural dominance in two ways: either by staying at home to establish Dublin as a rival cultural capital (Yeats, John Synge, and Augusta Gregory), or by bypassing London

19. For some pioneering attempts to connect the Revival to the Famine, see Luke Gibbons, "Montage, Modernism, and the City," in Transformations in Irish Culture (Cork: Cork University Press, 1996), 165-69; and Kevin Whelan, "The Memories of 'The Dead," Yale Journal of Criticism 15, no. 1 (2002): 59-97. 
altogether and migrating instead to Paris (Joyce, Beckett), thereby inserting Ireland into the mainstream of European culture from which centuries of British rule were felt to have had detached it. However much the Revivalist and the more vanguard wings of the "Irish Renaissance" may have differed otherwise, both were searching for an alternative to what they saw as the genteel philistinism of English Victorian culture.

For many Irish scholars - whether liberal or leftist, republican or revisionist-the most embarrassing aspect of the Revival is its folk culture idiom, its nativist or romantic nationalist tones, its "backward look" to the western seaboard or to imagined worlds of the Irish peasantry or of Celtic epic and saga. All of this lends Revivalist literature an archaic coloration distinctly at odds with conventional ideas of modernism as the brashly iconoclastic and cosmopolitan art of new times, new cityscapes, new materials, new technologies. In other words, if we take the "shock of the new" as the defining signature of modernism, then the Revivalist neoromantic celebration of the peasantry, the countryside, the Big House, all seem to be distinctly at odds with the modernist currents of the time.

But here again one has to assess the Revival in terms of the available cultural resources and longer cultural history out of which it emerged. European ancien régime "high culture" - the cultural matrix out of which European modernism developed and against which it rebelled-had its origins in the court cultures of the Renaissance and thrived thereafter under the patronage of the churches and the big and small absolutist states. The ballet, the opera, architecture, sculpture, the visual and performing arts all flourished in Europe within the carapace of the great continental absolutist courts-Bourbon, Habsburg, Hohenzollern, Romanov-and a host of minor central European courts, such as, most famously, Weimar or Bayreuth. Ireland was geographically on the periphery of this continent: it had no indigenous feudal or court culture of its own, and from early modern times it was under the colonial rule of the one major European country (England) that had the shortest-lived absolutist state, a constitutional monarchy with little power, and hence perhaps a court culture that was, by continental standards, rather undistinguished. The English court or state never matched the achievements in classical music, ballet, opera, or the visual or fine arts that its European counterparts did. England's major field of cultural achievement in the nineteenth century was in literature, and especially the novel; in nearly all of the other "high" arts (and the novel before its high modernist elevation was itself a "popular" rather than "high" art form) it trailed in the wake of its continental rivals. Anglo-Irish Dublin after the Union survived only as 
a declining satellite of this culturally unspectacular center, while Ireland's indigenous "high" Gaelic culture was arrested in its development by successive waves of colonization that demolished the Gaelic-speaking aristocracy and led to the suppression of the majority Catholic Church, a possible alternative source of patronage, until the nineteenth century. Without major institutions of aristocratic or ecclesiastic patronage, a "high" Gaelic intelligentsia or culture could not thrive, and over the centuries all aspects of that indigenous culture were subsequently reduced, as is common in colonial situations, to the status of a "folk culture": a culture valued more for its ethnographic interest, and the access it supposedly afforded to the vanishing past, than for its capacity to speak to the present. Since this meant that the Irish Revivalists, unlike the European modernists, had very little indigenous or vernacular post-Renaissance "high culture" of their own with or against which to work, it was scarcely surprising that they turned to folk and peasant materials, or to the premodern saga and epic literature of the pre-Christian past.

Nor was this turn to the countryside and the indigenous pagan or "deep" past for inspiration as utterly alien to other early European modernisms as some rather stereotyped conceptions of modernism would suggest. In France, for instance, the Impressionists conducted one of the earliest modernist rebellions against fossilized academic conventions, but Impressionist canvases were largely directed to the world of peasants, autumnal harvests, and the countryside rather than to that of cities and proletarians. When they did paint cityscapes, the Impressionists recorded artisanal markets and the boulevard cafés and leisure worlds of the Parisian petite bourgeoisie rather than the turbulent ultramodern landscape of the second industrial revolution. In Germany, Wagner's Ring cycle (1876) broke with nineteenth-century German operatic convention and paved the way for the emergence of modernist music, but the Wagnerian Gesamtkunstwerk looked to the world of pagan epic, medieval chivalry, and heroic emotion rather than to the contemporary industrial world for inspiration. In ballet, Stravinsky's The Firebird (1910) and Le Sacre du Printemps (1912), produced for Diaghilev's Ballets Russes, represented a shocking break with established conventions, but these works were deeply influenced by Russia's contemporary revival of folk culture rather than the new world of the factory, technology, or metropolis. Even in advanced industrial England, several of the most modernist writers-Joseph Conrad, D. H. Lawrence, T. E. Lawrence-drew more heavily for inspiration on the exotic and "primitive" outposts of empire rather than on the modern metropolis. In "the colonial 
world," too, as in Latin America, for instance, the first phase of modernism tried to reconcile the experimental advances of European vanguards with indigenous Aztec, Mayan, and peasant iconography.

In a variety of ways, then, a fascination with "primitive" cultures serves as a fundamental modernist stimulus (as the classics were to the Renaissance) through which to assault the perceived deficiencies of the modern world. ${ }^{20}$ The point for our purposes is that the late nineteenth-, early twentieth-century turn by Standish O'Grady, Yeats, Gregory, Synge, Patrick Pearse, Douglas Hyde, and the other Revivalists to what they took to be the premodern world was not totally out of step with other contemporary forms of early modernism. In Ireland, however, as in Russia, instead of seeking renewal among "primitive" cultures at the outer perimeters of empire, writers and artists looked to their own "primitives" at the domestic perimeters to serve as a spiritual counterresource to what they took to be the defilements of industrial and commercial civilization. If this turn to precapitalist aristocrat and peasant cultures, in Ireland as elsewhere, was often shot through with a reactionary worldview, then a more militantly experimental modernism that embraced technology, the machine, and the city was no guarantee of a progressive art or politics, either. Italian Futurism, to cite the obvious example, embraced the brave new world of the twentieth century with a missionary zeal, but while the Futurists attacked the monarchy and the Vatican, they also denigrated parliament and socialism, and trusted extreme Italian nationalism, imperialism, and war to blast the way to the future, whatever the human cost. In other words, the embrace in modernist hands of the archaic premodern worlds of aristocracy, epic past, and rural countryside or that of the metropolis and technology can be equally reactionary. What is politically decisive is not whether a modernist writer embraces the archaic or the modern elements - the country or the city-on this spectrum but rather how the dialectic between the two is elaborated in his or her work.

When Eagleton concludes, then, that "what is striking about Irish modernism is its overwhelmingly conservative tenor," arguing that the country was too rural and too technologically backward to produce a radical avant-garde on the continental European model, since "[t]here could be no exhilarating encounter between art and technology in such an industrially backward nation," the problem is not so much that this verdict is too harshly

20. See Marianna Torgovnick, Gone Primitive: Savage Intellects, Modern Lives (Chicago: University of Chicago Press, 1990); and David Richards, Masks of Difference: Cultural Representations in Literature, Anthropology, and Art (Cambridge: Cambridge University Press, 1994). 
negative (though it may be: when seen in a world-colonial context and not under exclusively Western eyes, the Irish Revival would prove tremendously inspiring-as the Harlem Renaissance and other episodes would suggest). The problem with the verdict, rather, is that it rests on a whole series of suppositions that need to be, but are not, critically tested. Working within a social formation that was neither continental European nor AngloAmerican in character, and thus lacking both the stimulus of the extensive ancien régime high cultures of the former fully as much as the economicotechnological dynamism of the latter, Ireland nonetheless produced several great modernist writers - first Synge and Yeats, then Joyce, later Beckettwho managed between them to span three successive phases or generations of European literary modernism. If in the works of the earliest of these modernists - Synge and Yeats - the dialectic between the archaic and the modern tended to be weighted toward the archaic, which was associated with value, and to denigrate the modern, equated with the loss of value, then this seems largely in keeping with a great deal of early or pre-World War I European modernism, when a strong sense of aristocratic disdain for the new society emerging out of the collapse of the old remained decisive. In Joyce's Ulysses, the same tension between the archaic and the modern remains fundamental. It is no longer manifest, however, in terms of a rivalry between premodern and modern cultural formations as in Yeats or Synge, but is reconfigured instead in terms of the tension between the modern city's complex geographic strata and multitemporalities and the mythic method designed to lend that landscape some sense of totalized form. But Joyce's work has already shifted the weight decisively toward the "modern" rather than the "archaic" end of the spectrum by moving his art away from the rural landscapes of his precursors and into a wholly urban Irish milieu, and by embracing the encyclopedic but mock-epic and post-heroic forms typical of modernism at its post-World War I meridian. In the postWorld War II work of Beckett, defined partly by his attempt to move beyond Joyce (as Joyce's was to press beyond Yeats's), the city in turn is abandoned for a null, devastated, shell-shocked, postapocalyptic, posthistorical wasteland, in which the whole project of modernity has already proleptically played itself out to a catastrophic denouement, and in which the detritus of the modern has consequently itself become archaic. Eagleton concludes that what unites these works is their common mandarinism and hence conservatism (there is, after all, no engagé such as Brecht on the Irish scenethough in this assumption, Eagleton, like everyone else, overlooks Mairtín Ó Cadhain, surely the most politically committed of the Irish modernist 
writers, his work regularly bypassed, however, because he wrote in Irish rather than in English). But what seems much more remarkable is the intellectual radicalism that drives the successive bearers of Irish modernism to work their way - with the relentlessness of a computer virus - through all of the major variations that the dialectic of the modern and the archaic (a dialectic constitutive of modernism tout court) will yield. In the works of the Irish modernists, that dialectic will continuously be extended and assaulted until, between them, the whole repertoire of "solutions" it will yield is exhausted or exploded.

While these writers produced several of the most challenging modernist masterpieces in the English language, the country still produced no extended modernist culture. This was not because Ireland was a premodern or traditional rural backwater too isolated from the rapids of twentiethcentury modernity to do so, but because it was in one broad sociohistorical sense too modern, since it had been, via colonialism, catapulted directly into modernity without ever having passed through the feudal stage and hence had so little of the vernacular "high culture" that many of its European neighbors had to work on. To put this otherwise, while in Europe it would take two world wars decisively to liquidate the hoary but obdurate old universe of the ancien régime, in Ireland, the late nineteenth-century Land Acts (which issued from the class struggles of the Land Wars) consigned the local aristocracy to their doom several decades earlier than the power of their counterparts in England and much of Europe would be dissolved. The attainment of bourgeois nationalist independence in what is now the Republic, moreover, took most of the island out of the titanic wars of selfdestruction that devastated much of the rest of continental Europe until the 1950s. A less conservative, less isolationist, and more engaged twentiethcentury history might have produced the social convulsions which might in turn have stimulated a more extended modernist culture, but if the Free State established a conservative society, that very conservatism bought its own shelter from Europe's successive plunges into self-destruction.

In the end, what distinguishes Irish modernism above all else from its European counterparts was not perhaps that it was on the whole much more or less conservative than other modernisms in other national contexts but that its literary modernism began so early ${ }^{21}$ and still managed to extend itself across several successive stages of modernist literary development,

21. See J. C. C. Mays's introduction in Poems and Exiles, by James Joyce (Harmondsworth: Penguin, 1992), xl-xli. 
yet without ever reaching much beyond literature. Except for a very modest modernism in painting-like literature, the most small-scale, individual, and artisanal of art forms - there were no substantive or extended modernist movements in Irish architecture, music, dance, sculpture, or municipal design. The experimental thrust of Irish modernism - in Wilde, Synge, Yeats, Sean O'Casey, Joyce, Beckett, and Ó Cadhain-was essentially linguistic in character, and it was in the carnival of language that the utopian dimensions of the Revival and the national struggle found sanctuary. While the fact that Irish modernism was so concentrated in literature may be explained partly as a response to a sense of linguistic alienation in English aggravated by the loss of Gaelic Irish culture, and partly due to the fact that literature is less immediately dependent on other large-scale political and economic institutional supports and constraints than other art formssuch as architecture, sculpture, or cinema, for example - this also ensures, however, that literature cannot so immediately translate its visions into the everyday lifeworld as these other media do. Because it was so confined to high literature, Irish modernism was inevitably, at a time when the bulk of the population had access only to primary education, largely divorced from the everyday lives of the broader Irish public. A modernism in cinema, music, architecture, public design, or the performing arts might have engaged public consciousness in more immediate ways than Ulysses or Yeats's late poetry or Endgame could ever expect to do. Ireland, then, had an exuberant literary modernism that survived across several generations, but already by the late 1920s, when the Irish revolution had petered out in a conservative partitionist state order on the island, that modernism was increasingly achieved not only in the geographical distance of European self-exile but at an emotional distance from the social movements and stimuli that had provided its initial momentum in the first instance.

\section{4}

For Anderson, as indeed for Jameson, it is the gradual disintegration of the coordinates that had sustained the modernist cultural field that has prepared the ground for the contemporary (post-seventies) ascendance of postmodernism. As Anderson conceives it, modernism continued as a defining cultural force until World War II, which delivered the final deathblow to the old agrarian and aristocratic elites and their way of life all across Europe. World War I had already mortally maimed these classes, but their traditional rival, the haute bourgeoisie, struggled to maintain the distinc- 
tive social and cultural universe of the old order for another twenty years, until it also began to dissolve as a class. The suggestion is not that class divisions have diminished since World War II or that overall levels of class mobility have significantly increased; what has changed, however, Anderson asserts, is that the sense of cultural distinction that characterized the old elites has dissolved in the new conditions of mass consumerism that developed in Western Europe in the contemporary period. In this situation, the old split between high and popular culture that had rested on the separation between well-educated elites and illiterate or semiliterate majorities began to lose its force. High culture is now cultivated by fractions of the university-educated bourgeoisie and middle classes, while the majority of all classes, rich and poor, are now attached to the mass entertainments of the culture industry. ${ }^{22}$ For long, Anderson argues, sociologists have debated the embourgeoisment of the European working classes, but in "a monetary world that knows no social fixities or stable identities," the encanaillement of the possessing classes represented the more significant phenomenon. ${ }^{23}$ In a context where the old academicist establishments and the narrow bourgeois mentalities against which it rebelled have both lost their force, modernism has lost much of its coherence and shock value, and can no longer maintain the oppositional stance it had once claimed $(O P, 86)$.

Secondly, whereas modernism had thrived on the excitements of the technological advances of the second industrial revolution, technological innovation acquired a more baleful cast by the second half of the century, with the invention of the atom bomb and the inauguration of the Cold War: in this climate, the malevolent specter of technological apocalypse had largely eclipsed the technological utopianism of the early twentieth century. Moreover, the most decisive technological advance of the postwar era, Anderson contends, was television, and especially color television, which only became generalized in the 1970s. TV and the new computer and digitalized communications technologies, he suggests, following Jameson, are essentially technologies of reproduction rather than production. Thus, the crucial difference between the wave of technological innovations released by the second industrial revolution and those of the late twentieth-century communications revolution was that the earlier innovations were themselves silent.

22. On this topic, see Néstor Garcia Canclini, "Latin American Contradictions: Modernism without Modernization?" in Hybrid Cultures: Strategies for Entering and Leaving Modernity (Minneapolis: University of Minnesota Press, 1995), 58.

23. Perry Anderson, The Origins of Postmodernity (London and New York: Verso, 1998), 85. Hereafter, this work is cited parenthetically in the text as $O P$. 
They had to be represented by other arts; they could not represent themselves. The new discourse- and image-producing technical environment of the postmodern is such, however, that all the arts are now increasingly cannibalized and mediated by these new communications technologies ( $O P$, 87-89).

Of the enabling conditions for modernism, the last to disappear was the specter of revolution. This, too, did not disappear overnight; it continued to haunt the post-World War II period, and, in the late sixties, the conjuncture of student and worker strikes across Western Europe, decolonization movements in the Third World, and the apparent prospect of a revitalized Communism after Stalin, together with the sexual revolution, created a revolutionary ferment not seen since the twenties. But this conjuncture proved a short Indian summer, and by the seventies the Right resumed control with Thatcher and Reagan. By the end of the eighties, Soviet Communism had collapsed, the Third World anticolonial revolutions had failed to deliver economic emancipation, the welfare state created by postwar social democracy in Western Europe was downsized, and the triumph of neoliberalism seemed assured.

It is, Anderson argues, in this new conjuncture that the new postmodernist field emerges into view. "Postmodernism emerged from the combination of a declassé ruling order, a mediatized technology, and a monochrome politics" $(O P, 92)$. Capitalism itself, he adds, entered a new phase after the postwar boom ended, characterized by the assault on organized industrial labor in the capitalist cores; by outsourcing to peripheries of the world system; by the dramatic rise of finance capital and exchange speculation relative to manufacturing; and by the vulgar nouveau riche consumerism and hedonism that has dominated the eighties and nineties. "The departure of aristocracy, the evanescence of the bourgeoisie, the erosion of workingclass confidence and identity, have altered the supports and targets of artistic practice in fundamental ways. It is not that alternative addressees have simply disappeared. New poles of oppositional identification have emerged in the postmodern period: gender, race, ecology, sexual orientation, regional or continental diversity. But these have to date constituted a weaker set of antagonisms" (OP, 104).

The postmodern cultural moment, for Anderson, lacks both the towering individual geniuses or the intransigent collective vanguard movements of the modernist period. Where new avant-gardes do appear, they are incorporated into the commodity market with unprecedented rapidity. Whereas the modernists had tended, broadly speaking, to ally themselves 
either with the élan of the old aristocracy or with the egalitarian dreams of a still-emergent, still-radical labor movement, or even in some instances with both, in the altered conditions that constitute the postmodern, the possibilities of imaginative investment in either the upper atmosphere of titled leisure or the lower dreams of manual labor have receded.

If these vectors of alterity are not available to postmodernism, which ones are? Here Anderson finds a model in Antonio Gramsci's conception of the European Renaissance and Reformation. Intellectually and aesthetically, the Renaissance was far in advance of the Reformation, but the Reformation, culturally coarser, more philistine and obscurantist, was a conservative reaction that nonetheless yielded a historical advance. The Renaissance had been an elite affair, confined to wealthy educated minorities; the Reformation involved half the common population of Europe. So although the Reformation coarsened and simplified the High Renaissance assault on medievalism, the passage of intellectual advance through the ordeal of popularization ultimately put the advances made by the Renaissance on a stronger and freer social foundation.

Can this Gramscian model of dilution and diffusion describe the relationship between modernism and postmodernism? Jameson's early work on postmodernism, Anderson believes, had intimated something of this kind. Increased levels of educational access and higher literacy, new information technologies, a more universal dependence on wage labor had, Jameson suggested, created something of a leveling process: not democratization, but nevertheless a kind of "plebianization" of high culture that the Left could only welcome. Viewed thus, postmodernism could be regarded to some extent as a welcome popularization of modernist sensibility and techniques. Anderson considers this idea, but ultimately rejects it, since he believes that the analogy with the Reformation will not hold. The Reformation, he argues, was a political movement of convulsive energy, unleashing civil wars all across Europe; it was an ideological insurgency against the premodern ideological order of the universal church. The period since the seventies has seen enormous global change, but the triumph of neoliberal capitalism has only rarely been something won by bottom-up popular struggle; mostly it has been compelled by top-down economic pressure mediated through international agencies servicing the interests of global capital $(O P, 112-14)$.

Anderson does sketch, however, what he identifies as a constitutive tension within the postmodernist cultural field, between its citra and ultra tendencies. The citra includes all those tendencies that have tended to dis- 
pense with the more difficult and inassimilable parts of modernism to make it more accessible; the ultra includes those tendencies that have attempted to radicalize modernism's negation of immediate gratification or sensuous intelligibility. The one attempts to adjust art to the ubiquity of commodification and the spectacle; the other attempts to elude this fate. In the postmodernist moment, however, the weight of the ultra to citra tendencies is clearly the inverse to that of the earlier modernist epoch, the seesaw has titled to the other end $(O P, 105-6)$. While it is certainly the case that much of the "Third World" has far lower degrees of consumption and much less advanced levels of technological development than those associated with Western postmodernism, the development of global communications systems-especially television-has ensured, Anderson suggests, "an incomparably greater degree of cultural penetration of the former Second and Third Worlds" than had been the case even as late as the sixties. In these conditions, postmodern forms make themselves felt well beyond the rich Western metropolitan regions, so that today there is little reason to doubt that "even the damned of the earth too have entered the kingdom of the spectacle" $(O P, 122)$.

\section{5}

To what extent, if any, might these relief maps of the postwar metropolitan landscape help to illuminate late twentieth-century Irish developments? Since 1958, when the Irish political elite finally abandoned economic autarchy, the southern Irish state's single major project has been to integrate the country into the European Union and global capitalism. The same period witnessed the introduction of new communications technologies, especially television, which brought the country into closer contact with the wider international political scene and with British and North American consumer society. There was the early but delusive hope that economic modernization could be achieved while maintaining intact the conservative Catholic social order consolidated after independence. Confronted since the seventies on a series of fronts-by the women's movement, the very different value system retailed in mass culture, and the top-down liberalization of state law required by EU membership-the Catholic Church initially rallied its forces to defeat successive attempts to loosen the bond between church and state and to liberalize sexual mores. By the nineties, that reactionary rally had ebbed considerably. The litany of clerical sex and child abuse scandals dredged to light during the last decade has massively 
dented the moral authority of the Catholic Church. This had been, in any event, weakening for some time, as more and more people simply ignored its teachings on sexual morality. This social process is best understood perhaps not so much in terms of "secularization" as in terms of a wholesale resocialization or reengineering of Irish bourgeois subjectivity and cultural hegemony. What has emerged in the wake of the old Catholic-nationalist order is not so much a more secular society as a new kind of social formation where subjectivity is decreasingly defined either in terms of citizenship or of adherence to communal church practices. Instead, it is increasingly articulated in terms of individual capacity to participate in various modes of consumer "lifestyle": a transformation in the technology of subject production as dramatic and far-reaching as that inaugurated in the nineteenth-century after the Famine.

The mediatization of Irish culture has also proceeded apace. While colonial Ireland was only lightly touched by the first and second industrial revolutions, and while independent Ireland circumvented, because of its neutrality, the nuclear dimensions of what Mandel has called the third technological revolution, the country has found itself during the last two decades (punctually, this time, no long time lag involved) a significant supply center for what we might call, extending Mandel, the "fourth" (computer) technological revolution. Hence, it has been able to overcome the peripherality suffered in earlier phases of capitalism to become a world center in the software industry. Ireland is now the second largest exporter of software in the world after the United States (60 percent of PC-based software in Europe originates from Ireland) and is lauded by economists as one of the most fully "open" or globalized economies in the world. ${ }^{24}$

The third defining coordinate of the postmodernist conjuncture, according to Anderson, is the exorcism of the specter of revolution and a corresponding diminishment of any sense of alternative futures. In the late sixties, Northern Ireland did experience a surge of revolutionary upheaval in the form of the civil rights campaign, which challenged Unionist domination of the North and in so doing threatened to upset the whole basis of the post-partition state settlement. The deliberate injection of violence into that campaign in the early 1970s, especially on Bloody Sunday, set the scene, however, for a long "dirty war" that unfolded against the backdrop of the grim international horizon of the Second Cold War. This viciously

24. Cited in Michael Cronin, "Speed Limits: Ireland, Globalisation, and the War against Time," in Reinventing Ireland: Culture, Society, and the Global Economy, ed. Peadar Kirby, Luke Gibbons, and Michael Cronin (London: Pluto Press, 2002), 56. 
conducted struggle mobilized and politicized the Northern Catholic working class and has impelled substantive reform of the Northern state, but republican insurgence was unable either to end partition or to overcome the divisions between the Protestant and Catholic working classes, which remain deeper than ever today.

The period since the seventies, then, has witnessed major sociocultural change and massive economic transformation in the Southern state and some substantive administrative reform in the Northern one. In both states, however, these positive transformations have gone hand in hand with an increasing subordination of society on the island as a whole to the dictates of a neoliberal economic order that has actually aggravated social inequality and led to the normalization of an individualistic consumerist ethos at the expense of social solidarity. Some of the smaller left political parties and some religious organizations have helped to temper the worst excesses of the existing economic order. But, as is the case globally with the Left, none has been able to articulate what the economic-cultural basis for some alternative kind of society might be. While there is much in recent Irish history that would require us to reject or temper Anderson's dejected conception of the post-seventies' period as one characterized solely by an unbroken litany of defeats, the very constricted sense of available alternatives to the existing neoliberal economic regime is as decisive a feature of the current sociopolitical climate in Ireland as elsewhere. Indeed, in Ireland since the sixties - as in what was once Eastern Europe and in many places in the erstwhile "colonial world" today - the surest sign of the ascendancy of the new neoliberal regime is that the country's ongoing integration into the world-economic system is so widely credited as a process of emancipation from a misguided revolutionary past. ${ }^{25}$

Nevertheless, while the coordinates of postmodernism delineated by Anderson and Jameson identify the wider context and constraints within which contemporary Irish cultural change can usefully be analyzed, the specific character of the Irish scene ought not to be effaced. For both of them, as we have seen, postmodernism emerges in a cultural climate determined primarily by the waning of an earlier efflorescence of modernism. However, while Ireland produced, as has been noted, an ambitious literary modernism, the country was in no position to support an extended modernist culture beyond the literary field. In fact, even in the literary field the cultural dominant

25. The best accounts of the cultural dynamics of Irish modernization since the sixties are Luke Gibbons's Transformations in Irish Culture (Cork: Cork University Press, 1996), and Conor McCarthy's Modernisation: Crisis and Culture in Ireland, 1969-1992 (Dublin: Four Courts Press, 2000). 
in Ireland during the decades between independence and the end of the twentieth century was not modernism at all but rather naturalism. Born of the blighted dreams of the Irish revolution, this naturalism was, in essence, an aesthetic of diminished expectations that set out to deprogram the romantic utopian impulses of the literature of the Revival. Where Revivalist literature insisted on the possibility of a revitalized putatively archaic Irish culture heroically resistant to the defilements of metropolitan modernity, naturalism negated this utopian idealism by insisting on the dreary provincial squalor of Irish life. In the theater, this disillusioned naturalism was already installed as the dominant house style in the Abbey by midcentury: the reigning genres were political farces, peasant comedies, rural and kitchen dramas. Naturalism's ascendancy in poetry was marked by Patrick Kavanagh's The Great Hunger (1942); Kavanagh (and not Yeats) became the dominant model for most Irish poets right into the present. In narrative fiction, the early naturalistic Joyce of Dubliners and Portrait of the Artist (and not Ulysses) exerted the most decisive and extensive influence on the development of Irish writing in the postindependence period.

In its French inception, the naturalist novel had provoked intense hostility because it imaginatively explored previously uncharted territories of lower-class urban experience-slums, back streets, brothels, prisons, asylums, and the modalities of petit bourgeois poverty and vice-and thus offended official morality and accepted definitions of novelistic good taste. But Irish naturalism has been concentrated (with important exceptions) overwhelmingly in small-town and rural Ireland, the fictional territory of writers such as Kate O'Brien, Liam O'Flaherty, Sean O'Faoláin, Edna O'Brien, John McGahern, Tom Murphy, and William Trevor. Like its French counterpart, Irish naturalism was also in its inception a dissident and reformist aesthetic: it measured the distance between the official state ideology of Irish Ireland and its tawdry reality. The naturalist writers probed-with an intimate knowledge of the local terrain conspicuously absent in much of the literature of the Revival-the social and sexual traumas that official Irish culture would not acknowledge, and in so doing many incurred the wrath not only of state censors but of the reading public for scandalizing their own society before an allegedly hostile Anglo-American audience.

But while naturalism was undoubtedly a dissident and reformist aesthetic, it would be difficult to regard it in retrospect as a radical one. It protested against the sordid, hypocritical, petty corruption of small-town or rural Ireland, its cultural and libidinal immiseration. Yet, while it disclosed the cramped lives this society afforded, it also consistently reduced-in the manner habitual to naturalism - that society to the sordid conditions it pro- 
tested. Naturalism is a socially engaged form, but it is a literary mode usually focalized through the consciousness of characters so socially isolated and temperamentally alienated from their communities that any sense of social protest is typically smothered by a pervading climate of entropy and fatalism. In Irish naturalist fiction, protagonists usually survive their deathly social condition only if they can escape or emigrate; to remain within or committed to the local community is to atrophy with it.

No one can doubt that the problems depicted in naturalism were actual and pressing; what can be questioned is the inference that the communities depicted were so helplessly paralyzed, so denuded of internal dissident forces and resources, as naturalism typically indicates. Stylistically speaking, moreover, naturalism's formal and linguistic conservatism aesthetically reproduced that very sense of cramped ambition and narrow limitation which naturalism thematically denounced in society at large. Irish modernism might have detached itself from social engagement and in so doing displaced its utopian energies into linguistic and formal inventiveness; naturalism, by contrast, remained socially committed, but its arthritic aesthetic conservatism inadvertently replicated the dour social conservatism of Irish society against which it set itself. ${ }^{26}$ Thus, in many respects, the naturalists became a symbol of the very condition they protested. It remains today a critical commonplace to contrast Yeats's imaginary romantic Ireland with the tougher-minded realism of a Kavanagh, O'Faoláin, or McGahern, but Yeats was no less scornful of the society that emerged after independence than they; indeed, he was perhaps even more intransigently critical and unreconciled. The real difference is that while Yeats conceived of this provincial and puritanical new Ireland as only too typical of the bourgeois-industrial modernity he detested, the naturalists were convinced that the ills of postindependence Ireland were to be explained, rather, by its lamentably archaic rural social order, and that their task, therefore, was to release it into modernity. Both were agreed that the new Ireland was a disappointment; where they differed was that while Yeats attributed its shortcomings to its embrace of the modern, the naturalists attributed the same defects to the supposedly archaic character of Irish society that impeded it from fully entering the modern.

Once the economic modernization drive of the sixties got under way,

26. For a more extended discussion of Irish naturalism, see my "Modernization and Aesthetic Ideology in Contemporary Irish Culture," in Writing in the Irish Republic: Literature, Culture, Politics, 1949-1999, ed. Ray Ryan (Houndmills: Macmillan Press Ltd., 2000), 105-29. 
an extensive academic and journalistic literature emerged in Ireland that sought to identify those cultural factors that were impeding the development of a modern industrial enterprise culture. Fianna Fáil's version of nationalism, the rural "traditionalism" of the countryside, and the inordinate influence of the Catholic Church featured obsessively as mainstays of Irish backwardness in this literature. In this ideological climate, the bleak conception of postindependence Ireland fashioned in Irish naturalist literature was now pressed into the service of the wider cultural program of capitalist modernization. Since the naturalist aesthetic, like modernization discourse, insisted on the insular, static, monochromatic, and entropic quality of postindependence Irish life, and since mass culture offered a tantalizing vision of the unlimited bounty of metropolitan culture, it was all too easy to market the country's insertion into international consumer capitalism as a veritable ticket out of the poorhouse of independence into a carnival of libidinal and cultural excitement.

Thus, the real cultural dominant in postindependence Ireland was naturalism, not modernism. Hence the emergent cultural dominant of the present moment might be described not so much as "postmodernism" as a kind of neo- or postnaturalism. Some of the most internationally feted, commercially successful, and critically debated "new Irish" works of the last decade fall into a category of this sort. Brian Friel's Dancing at Lughnasa, Martin McDonagh's The Leenane Trilogy, Marina Carr's By the Bog of Cats and On Raftery's Hill, and Patrick McCabe's 1992 novel The Butcher Boy, later filmed by Neil Jordan in 1997, can all be read as signposts to the emergence and consolidation of this new aesthetic trend. A parallel development may be observed in Northern Ireland, where the more familiar "Northern thriller," romance-across-the-divide, and bildungsroman conventions consolidated since the seventies have been superseded in the nineties by more ludic versions of the same genres, a trend exemplified by works such as Neil Jordan's The Crying Game, Colin Bateman's Divorcing Jack, and Robert MacLiam Wilson's Eureka Street. ${ }^{27}$ In these works, the old naturalism has, in recent decades, acquired the high voltage of new technical innovations, some new Viagra of hectic experiment or extravagance, to resuscitate it into some new life or half-life.

Of these works, Friel's anomic Ballybeg in Dancing at Lughnasa is closest in narrative method and milieu to the established norm of Irish

27. See Richard Kirkland's incisive overview of contemporary developments in Northern Irish narrative fiction in his Identity Parades: Northern Irish Culture and Dissident Subjects (Liverpool: Liverpool University Press, 2002). 
naturalist drama. But it was the all-woman Dionysian dance scene that lent the play that startling burst of manic energy (all the more striking for being so alien to its overarching naturalist ambience) that mesmerized audiences and critics alike. The Irish midland settings in Carr's plays also ostensibly recall the old naturalist drama, but her characters display extremes of squalor, depravity, and psychotic behavior violently at odds with the more restrained politesse of the older naturalism. McDonagh's Leenane Trilogy inhabits a similar territory, but his is a more self-consciously darkened-down but also camped-up and comic world comprised of collages of the older naturalist conventions, settings, and formulas. In fiction, McCabe's Butcher Boy also pushes naturalism in the same comic-grotesque direction. In that novel, the conventional realistic depiction of a depressed small Irish town is transformed by filtering the narrative through the deranged Francie's apocalyptic imagination, in which Irish Catholic and British and American forms of pop-culture millenarianism promiscuously commingle. By this means, the more familiar naturalistic renditions of the rickety end of de Valera's Ireland intersect with and are aggravated and quickened by Cold War nightmares of nuclear catastrophe and Catholic fantasies of the end of the world. The result is an eclectic tragicomic vision of disintegration that inserts the national sense of an ending into a wider global one.

It is difficult to know at this early stage how best to diagnose the significance of this emergent aesthetic trend. On the one hand, the new neonaturalism would seem to signal a decisive disintegration of a fundamental paradigm of postindependence culture: the once dominant naturalist aesthetic is not displaced by some new aesthetic agenda, however; instead, the old naturalism is denaturalized by pushing its typical content and conventions to violent or kitschy extremes. In other words, the works of Carr, McDonagh, McCabe, and (in the different context of the North) Bateman and MacLiam Wilson continue to exploit the same emotional territories charted by the earlier naturalists, but they do so with a kind of formal eclecticism and hectic bravura alien to the older forms. Their neonaturalism might, on the one hand, be read positively as an objective correlative of the contemporary condition: a period of exuberant social flux that cannot, however hectically it bids to do so, dispel the traumatic memory of the past from which it wishes to escape. Alternatively, it might just as plausibly be argued that these works represent an essentially superficial renovation of an old aesthetic-a naturalism on steroids is still naturalism - since the formal experiments remain shackled to the same dystopian, entropic, naturalist worldview. Where the thematic content of the once-dominant older naturalism 
was radical but its form and treatment conservative, the new neonaturalism might be said simply to reverse this ratio: the fundamental conception and diagnosis of Irish society rehearsed in the new neonaturalism is very familiar indeed, the formal experimentation a desperate last-ditch attempt, perhaps, to lend that inherited content a spurious radicalism.

The contemporary Irish literary field, then, is structured by the intersection of a number of distinct aesthetic modes and agendas. An established literary naturalism, identified primarily with some of the now senior reputations in Irish fiction such as McGahern, O'Brien, Friel, Murphy, and the late Brian Moore, and with a host of lesser figures, remains a dominant though seemingly declining force. A newer neonaturalist narrative aesthetic, associated primarily with a younger generation of writers, has recently emerged to challenge, though also in some ways thematically to sustain and prolong that dominance by other means. The canonical figures of Irish modernism-Wilde, Synge, Yeats, Joyce, and Beckett-continue to tower like a literary Mount Rushmore over the contemporary scene. The belated legatees to this older modernism, such as Thomas Kinsella, Derek Mahon, Trevor Joyce, and Catherine Walsh, now operating in unseasonable conditions almost wholly inhospitable to modernism, have found themselves sidelined by a critical establishment more preoccupied with writers whose styles represent late-lyrical versions of naturalism - such as Seamus Heaney or Michael Longley - or with those whose works appear more easily accommodated to wider postmodernist international currents-such as John Banville, Paul Muldoon, and Medbh McGuckian. Distinctions between these belated modernist and postmodernist agendas seem increasingly hazardous and unstable, in any event, because in the period since World War II modernism generally has surrendered both its vanguardist faith in the transfigurative power of art and its "mandarin" commitment to encyclopedic and autotelic works of art that aspired to become hieratic texts to an entire culture. ${ }^{28}$

Even as the achievements of the major modernists recede in time, therefore, and even as their works lose some of their initial power to shock as they become embalmed and institutionalized by the university and heritage industries alike, they continue-because of the grand scale of their ambition, radical integrity of their vision, and scope of their erudition-to overshadow all subsequent achievements. However much contemporary Irish literature may aspire to outflank or leave modernism behind, therefore, it still

28. The major exception is Thomas Kinsella. While a veritable critical industry has emerged around Heaney, Kinsella's work has received much less sustained attention and has even been excluded from some recent anthologies. 
languishes in modernism's wake. Works of some merit continue to appear in all of the different aesthetic modes that intersect to constitute the current Irish literary field, but truly significant change perhaps will require work charged with ambition sufficient to disturb and reconfigure that whole literary field itself.

While modernism and naturalism may be at opposite ends of the spectrum where the subject of verisimilitude or representational realism is concerned, in an Irish context they have both been institutionally processed in terms of their apparently shared antagonism to what is commonly characterized as the Revival's romantic "flight from reality." ${ }^{29}$ In the overarching context of the country's integration into Europe and global capital, that is, the social function served by each has proved largely complementary: naturalism is generally lauded as the necessary gritty realistic corrective to Revivalist romanticism and idealism; modernism is championed as the aesthetic that best expresses the country's post-sixties' disdain for cultural nativism and receptiveness to international modernity. For any new literature to emerge, a new cultural criticism capable of shattering this congealed critical consensus (the literary critical outrider of modernization theory) will also be indispensable.

\section{6}

The most decisive shift in contemporary Irish culture in recent decades, therefore, is not that comprised by recent mutations within the literary field itself but rather the apparent displacement of literature tout court from the central position it had occupied since the Revival. That Revival, as I remarked earlier, was an overwhelmingly literary phenomenon whose "giants" were all writers. Contemporary Irish writing, even at its very best, has produced no writers of comparable ambition, erudition, complexity, or international stature, and in fact the most internationally distinguished and consistently innovative figures of the contemporary Irish cultural scene at present are not its writers but its singers and musicians. Given its population and the size of its domestic market, Irish traditional, folk, and rock music forms have enjoyed a remarkable presence on the domestic and global music scene over the past several decades. Traditional music, once thought a residual western seaboard phenomenon on the verge of extinction, has witnessed a striking resurgence in recent decades-one that has secured

29. This description of the Revival is John Wilson Foster's in Colonial Consequences: Essays in Irish Literature and Culture (Dublin: Lilliput Press, 1991), 50. 
its popularity at both the urban and rural community level-and it is now the object of serious academic study as well. Irish folk music-drawing on both Irish traditional and folk and wider international influences-has also produced a whole series of figures, such as Luke Kelly, Donal Lunny, Andy Irvine, Paul Brady, Dolores Keane, Christy Moore, Mairéad and Tríona Ní Dhomhnaill, and many others, whose works have earned them a popular domestic and international audience. Meanwhile, in the more high-profile rock scene, Irish artists such as Van Morrison, Rory Gallagher, Bob Geldolf, U2, Sinéad O'Connor, and the Pogues appear to have secured for themselves a place in the history of international popular music that few of their literary peers could claim in the history of contemporary international literature.

The vitality of the contemporary Irish music scene is not something that should be attributed to the Celtic Tiger boom period, which ought more properly to be associated with the lip-synced pap of "boy bands" such as Boyzone or Westlife. The roots of Irish music's current success might be traced back, rather, to the international folk revival of the 1960s, which created an appreciative new international and domestic audience for Irish traditional and folk music, and to the concurrent abandonment by the state of its attempt to generate an indigenous Irish musical "high culture" or "art music" by means of an arranged marriage of Irish folk and European classical traditions. ${ }^{30}$ Internationally, this was also a period when, in Derek Scott's phrase, postmodernism "ousted [modernist] notions of universalism, internationalism and 'art for art's sake,' and replaced them with concerns for the values of specific cultures and their differences." 31 For Scott, the belief in a universal aesthetic that transcends social and cultural context lay behind the internationalist aspirations of musical modernism; this aspiration has been displaced, he contends, since the sixties, by a postmodern cultural relativism, signaled both by a resurgent interest in "ethnic music" (and the rise of ethnomusicology) and the increasing similarity in the marketing techniques used for the classical and pop music repertoires.

In the space opened by these developments, a whole series of Irish individuals and groups, practicing very diverse musical styles, emerged. These included traditional and folk groups such as Planxty, the Bothy Band, Ceoltóirí Cualann, the Chieftains, De Danann, and Altan, and bands such as

30. See Marie McCarthy, Passing It On: The Transmission of Music in Irish Culture (Cork: Cork University Press, 1999), chap. 6.

31. Derek Scott, "Postmodernism and Music," in The Icon Critical Dictionary of Postmodern Thought, ed. Stuart Sim (London and New York: Routledge, 1998), 135. 
Horslips, Moving Hearts, Scullion, Clannad, and the Pogues, who pioneered experimental syntheses of international rock and traditional Irish arrangements. In the works of early rock groups such as the Boomtown Rats and later bands and individuals such as U2, the Undertones, the Cranberries, and Sinéad O'Connor, the international rock element vastly outweighs any indigenous Irish sound or form. What is important here, however, is not the listing of individual artists and groups but the fact that a critical mass of musical talent, working domestically in a sustained manner over several decades, and in a variety of fields from traditional through classical to punk, has produced a music that has engaged and extended, rather than simply disowned, its indigenous heritage. In the Pogues's sometimes raucous, sometimes lyrical, blending of London punk and Irish folk, in collaborations such as that between Van Morrison and the Chieftains, in Sinéad O'Connor's haunting renditions of traditional ballads, in the heterogeneous versions of "Celtic rock" developed from Horslips to Clannad to Moving Hearts, as well as in the works of a host of individual composers, singersongwriters, and musicians, local and international forms have achieved creative interaction.

In a country in which literary critics monopolize cultural debate and in which specialists in European classical music dominate the academic study of music at the university level, the sociocultural significance of this quite dramatic musical "renaissance," which has now extended in multiple directions over several decades, has received astonishingly little critical analysis. ${ }^{32}$ It would be tempting to construe the phenomenon as a kind of latterday version of the earlier Revival period, as both moments have involved productive critical encounters between local materials and wider international experiments and styles (as well, inevitably, as producing a good deal of "cod celticism"). Yet while the comparison is common, the analogy is ultimately misleading, since the differences between the two moments and phenomena are as significant as any similarities. The most successful Irish writers to emerge from the late nineteenth-century Revival were committed to a high modernism in which cultural production was directed, to use Pierre Bourdieu's terms, toward the field of restricted production, where the accumulation of long-term symbolic capital was prized above short-term economic profit. Thus, while works such as Ulysses or Waiting for Godot may

32. See Patrick Zuk, "Music and Nationalism," Journal of Music in Ireland 1 (January/ February 2002): 5-9. Irish feminist cultural criticism seems no less restrictively tied to the written word. Irish academic feminism has still to produce a single major study of contemporary Irish women musicians, singers, or composers. 
have freely drawn on mass culture, these were nonetheless formally innovative, oblique, vanguardist texts that resisted capitulation to "the culture industry," though their formal difficulty also steered them toward a restricted highly educated elite audience. For the most part, however, the works produced by the most internationally feted artists to have emerged from the current Irish musical ferment are aimed at what Bourdieu calls the field of largescale cultural production: that is, at the more popular end of the market that literary modernism resisted. ${ }^{33}$ Indeed, those individuals and groups, such as U2 most notably, that attained the most spectacular success have become themselves microversions of multinational enterprises complete with their own extended staff, public relations and image development teams, not to mention multimillion turnovers and investment profiles. In the industrial structures of the music industry, business people play a more decisive role than any aesthetic mediators (fellow practitioners, critics, music historians) in key production decisions. Considerations about what or what not to produce are based less on personal feedback from artistic peers or audiences than on electronic techniques of market research, and considerations such as whether the musical product will accommodate the needs of other media outlets such as radio and television take precedence over the independent choices of the musicians. This capitalization of culture may not be entirely new (and it is much more extensive in rock than in the traditional, folk, or classical strands of the current ferment, which are often mediated to the public through quite different circuits), but when cultural production takes corporate form, the interplay between capital and culture is certainly intensified to entirely unprecedented levels.

Thus, as the Irish cultural field has been expanded and reconfigured in the last two decades, so too has its weight undoubtedly shifted toward corporatized forms of cultural production and consumption, the operations and consequences of which Irish cultural critics, mesmerized by the "great leap forward" of the Celtic Tiger, have mostly ignored. But while this situation clearly calls for something more than the kind of dizzy Disneyfied excitement and self-congratulation that has characterized so much Irish cultural criticism of late, something more rigorous than bargain-basement-standard Adornean diatribes about commercialization or the culture industry is also required. The capacity to produce a radical Irish culture critically responsive to the demands of the new global conjuncture has by no means been eliminated, though the conditions, circuits, and modalities through which it might flourish need constantly to be reimagined, cultivated, and renovated.

33. See Pierre Bourdieu, “The Market of Symbolic Goods," Poetics 14 (1985): 13-44. 